\title{
Beggars, Vagrants and Romanies Repression and Persecution in Portuguese Society (14th-18th Centuries)
}

\author{
Laurinda Abreu
}

The social exclusion and the fragility that the present economic situation bears is not a new phenomena in Europe. Forced by uncontrolled circumstances or as a result of individual or group choices, the non integration into society carries elements of disorder, insecurity and fear that go through all times and spaces. The trauma brought on by the Black Death, associated with the process of transformation of the dominant political model in Europe and to changes in the economic structures, made it easier to implement actions to discipline society and to reduce the violence. In the Europe that witnessed the construction of the Early Modern States, those who did not have an occupation, refused to work or search for a "master", were stigmatized, severely persecuted, marginalized and expelled from their communities.

What I propose here is to go back to the first regulations against vagrancy and idleness in Portugal. Created and developed in crucial moments of transformation of the economic and social structures, these policies help to understand the beginning of a historical process - of European dimension - which, in a certain way, is extended to some of the present social attitudes, at a global scale.

With no substantial differences to the other European States' diplomas promulgated at the same time ${ }^{1}$, the Portuguese laws against the false beggars, the vagabonds and everyone refusing to work had two particularities: they represented the thought of a central government and were conceived to be applied at a national scale, which was at that time relatively exceptional.

A more precise analysis of these normative texts gives important indications on the way the concept of vagrancy was socially defined - "the idle, the lazy and the dangerous" - and the means developed to deal with such people. The inclusion of the Romanies in these texts at the beginning of the 16th century sheds some light on the subjacent criteria of the identification as a group, and on the reasons why

1 Cf. Robert Jütte, Poverty and Deviance in Early Modern Europe, (Cambridge, 1994), pp. 143-200. 
they were marginalized and controlled. Going back to the beginning of the process of controlling beggars, vagrants and Romanies, offers new elements so as to make the whole process understandable.

\section{And Those that "don't want to serve will be publicly beaten and expelled from our kingdoms" ${ }^{2}$ the Medieval Definition of the Deserving Poor}

The idea of the generosity of the medieval people, ready to share their daily bread that in many cases was not even enough for themselves, perpetuated by several authors, is strongly rooted in the European historiography emphasising the context of the Christian worldview that attributed specific roles to the rich and poor. Without denying this idea, it is justified to re-evaluate it in the light of the sources that support it: documents attesting good social practices towards the poor and the beggars, reports on the budgets of the monasteries and convents showing their charitable donations, religious literature, hagiographies and saints' lives. In general terms, the main purpose of this documental corpus was to teach and catechise society in the Christian values. And it is in that sense that it has to be taken into account.

This does not mean that the feelings of tolerance, benevolence and charity did not exist or were exceptional in Medieval Times. They existed but have to be analysed at different scales. A common situation for the majority of the population, poverty was a worrying target for some of the sectors of society, justifying charitable actions, that the Christian doctrine stimulated, whether in the form of single and more private donations, whether in more institutional and public projects. As $\mathrm{Mi}$ chel Mollat mentioned, one of the biggest social concerns of the time was to prevent the poor from going beyond the threshold that drove them to poverty and misery ${ }^{3}$.

It was precisely to protect their more vulnerable members that the communities organized themselves creating structures of support that normally resolved the problems at a local level, through informal support - family or vicinal -, or through the institutions, either of individual foundation and management or confraternal or

2 A preliminary version of this paper was present as an introduction to the book Monitoring health status and vulnerable groups in Europe: past and present, Laurinda Abreu and Janos Sandor (ed.), Santiago de Compostela, 2006.

3 Cf. Michel Mollat, "Pauvres et assistes au Moyen Age", A Pobreza e a Assistência aos Pobres na Peninsula Ibérica durante a Idade Média. Actas das 1as Jornadas Luso-Espanholas de História Medieval, Lisboa 25-30 de Setembro de 1972 (Lisboa, 1973), vol. I, pp. 13-15. 
even parochial ${ }^{4}$, not forgetting the important role that the monastic orders played in this field ${ }^{5}$. The social definition of the deserving poor, which was shared earlier by the population is clear: the ill, the elderly and the poor in shame, but also the pilgrims, the widows, the orphans and the abandoned children, the poor prisoners and, surely enough, the captives captured by the Moorish, due to the religious risk they ran. Hospitals and brotherhoods were founded for them, food, clothes and money were regularly distributed and spiritual support was provided.

However, the urban development and the economic and social transformations initiated in the first half of the 14th century, and precipitated with the Black Plague, would make the discrepancy between the capacity to create poor relief resources and the real necessities of the populations very clear. In Portugal, as in the rest of Europe, the crises of the 14th century, even if of a different dimension and amplitude, would breach unstable balances, dragging "hoards" of destitute to the urban centres to look for work, alms or assistance. Thus, one of the first problems that the late-medieval generosity came across was of quantitative order or, better, on the difference of greatness. In fact, in spite of the generosity of the religious institutions, ecclesiastics, common people or royal houses and the poor integration in the "economy of the salvation", that multiplied all sorts of pious foundations in the benefit of donators, the offer of poor relief resources was far from that of the real necessities. To select the targets became, therefore, a practical question, of major importance. To know who, among the crowds, truly needed assistance or were impostors, became a priority as the disequilibrium between the offer/search was more prominent.

At the same moment there was a highly-precise reaction against those who cheated and deceived and these were, according to the social perceptions, the lazy, the vagrants, the false beggars and the foreigners whose source of income was unknown. To sum up, the wandering people, or, to quote the representatives of the citizens at the Courts of Lisbon in 1371, the ones "that wander around". The adjective used to identify them - "wandering" - elucidates the stigma that had been imposed on them and the social repercussion behind their profile: uprooted people without social duties, refusing to work, even though they had the capacity for it ${ }^{7}$. It was presumed, in these cases, that they lived "on misdeeds". That is to say, deceiv-

4 Cf. Maria Helena da Cruz Coelho, "As confrarias medievais portuguesas: espaços de solidariedade na vida e na morte", in Cofradías, grémios, solidaridades en la Europa Medieval, Actas XIX Semana de Estudios Medievales, Estella 92, 1992.

5 Cf. José Mattoso, "O ideal da pobreza e as ordens monásticas em Portugal durante os séculos XI-XIII", in A Pobreza e a Assistência aos Pobres na Peninsula Ibérica durante a Idade Média, tome II, pp. 637-670.

6 Courts of Lisbon, of the 8th of August 1371, quoted in Portugaliae Monumenta Misericordiarum, (henceforth PMM) (Lisboa, 2003), vol. 2, doc. 62, p. 125.

7 Ordenações Afonsinas (Lisboa, 1984), vol. IV, pp. 141-142. 
ing, stealing and begging just out of laziness. The feeling of the social injustice that is present among the "honest people" is made explicit by the violence of the words of the population: let them "be banished and expelled from our kingdom" ${ }^{8}$.

The genealogy of the Portuguese medieval legislation against beggary and vagrancy ' can be divided into two periods chronologically divided by the Law of the Sesmarias, of 1375. In the first, we can integrate the diploma of D. Afonso II, of 1211, that determined the expulsion of the idle ones; the 1349 law, that condemned the false beggars; the D. Fernando deliberation, taken in sequence of the 1371 protests, above mentioned, which delegated power to the local authorities to deal with the delinquents and vagabonds and, finally, the Law of the Sesmarias, this one ending the first period and starting a new phase in what concerns the control of the beggars. Especially studied as a source for the promotion and development of the country through the recovery of agriculture, abandoned and with lack of labour as a consequence of the Black Plague, the social clutters that it provoked, the epidemics that followed, and of the general demographic cut, the Law of the Sesmarias initiates, in fact, a new stage in social policy terms and this for two reasons: because it systemizes disperse measures previously taken, giving important orientations to the beggary phenomena, representing the first effectively structuralized and consistent political answer on the question ${ }^{10}$, but, above all, because it will serve as a matrix to the 16th and 17 th century laws against beggary and vagrancy.

Using the arguments that Juan Luis Vives would propose 150 years later, the law convokes the biblical texts to condemn idleness and to restrict begging. Considering, for instance, that not all physical handicaps should give direct access to beg, it should be limited to the very weak, very old or very ill. Mirroring previous social attitudes, the Law of the Sesmarias incorporated the difference between the true and the false poor, or rather, between those who had the right to beg and those who "scrounged around shamelessly" 11 and hence considered more exigent and more dangerous, ready to assume aggressive and criminal behaviour. As a matter of fact, this law, put forward by the central government and applicable to the whole country, already included most of the measures that would be considered the basis of Early Modern Period policies in what concerned the fight against beggary and vagrancy, even listing the ways of facing it. For instance, proposing an amazing, relatively elaborate information gathering system which, at the local level, would serve to find out the lifestyle of each inhabitant and to transmit it through a welldefined hierarchy that reached the higher agents of the king, responsible for

8 Courts of Lisbon of 1410, quoted in PMM, vol 2, doc. 64, p. 126. Also, Courts of Santarém, 1418, quoted in PMM, vol. 2, doc. 65, p. 126.

9 About the subject, see Humberto Baquero Moreno, Marginalidade e Conflitos Sociais em Portugal nos Séculos XIV e XV (Lisboa, 1985), especially footnote nr. 13 of p. 27.

10 Ordenaçôes Afonsinas, book IV, Das Sesmarias, titile LXXXI, 1375, pp. 281-304.

11 Will of the 25th of January of 1349 (PMM, vol. II, p. 138). 
authorising beggary and condemning those who did not abide by the rules - begging without a licence ${ }^{12}$.

Generally speaking, registered in the Law of the Sesmarias, even if only as a draft, the main elements that were considered revolutionary in Vives' discourse ${ }^{13}$ : the division of the beggars between those who were apt for work and those who were impotent; their control and inspection; the pressing question of the work; the special care to be taken with the ashamed poor ${ }^{14}$. In a long term analysis, the most significant alteration that was made to the Law of the Sesmarias occurred at the beginning of the following century and foresaw the possibility of the non-authorized beggars falling into slavery, having to serve almost for free whoever requested them, a measure that was not applied to the foreigners until 1427, when the law became general ${ }^{15}$, precisely when the king was requested in courts, that, as was determined by D. Fernando, the municipal authorities should recuperate their authority in the attribution for beggary licenses ${ }^{16}$, pretension, repeated again in the 1481-1482 courts $^{17}$, followed by the petition to arrest those who were found begging without authorization, as the Ordenações Afonsinas already determined, ratifying the decision that D. João I took in the Évora courts, probably, in $1408^{18}$.

In conclusion, similarly to what happened in other parts of Europe, the limitation of the beggary, the repression of the one exerted illegitimately and the fight against vagrancy, have an old history in Portugal. And it was a determinant for the definition of the deserving poor and, in consequence, of the making of the concept of poverty, moulding the social perceptions and representations, that had an extraordinary longevity although it characterized a complex social reality, fluid in time and in the vocabulary that defined it.

Related to the previous point, another element that was important in the social representations and in the legal discourses that, supposedly, answer them, is the association between the practice of charity and assistance with the necessity of

$12 P M M, 126$, doc. 65, dated from 1418.

13 Except for the individualization of the foreigners, incorporated in the Portuguese law only later on.

14 Jean Luis Vives, "Del socorro de los pobres, o de las necesidades humanas", Biblioteca de autores españoles, vol. LXV (Madrid, 1953). A careful analysis can be found in Linda Martz, Poverty and welfare in Habsburg Spain (Cambridge, 1983), pp. 7-15.

15 Far from, however, the violence of the law promulgated by Toledo, in 1400, that foresaw cutting the ears and even the death of the vagabonds. Cf. Linda Martz, op. cit, p. 12. Armindo de Sousa, As cortes medievais portuguesas (1385-1490) (Porto, 1990), vol. II, p. 280.

16 Similar determination is taken after the Courts of Madrid, of 1435. Cf. Juan Torres Fontes, "El concepto concejil Murciano de Limosna en el siglo XV", in A Pobreza e a Assistência aos Pobres na Peninsula Ibérica durante a Idade Média, vol. II, p. 845.

17 Maria José Pimenta Ferro well demonstated in Pobreza e Morte em Portugal na Idade Média (Lisboa, 1989), p. 39.

18 Ordenaçôes Afonsinas, book IV, title. XXXIV, pp. 141-142. 
workers for economic development. It is known that the circumstances of the moment propitiated such links but it is also true that these preoccupations would be made law in the following centuries; the moral aspects always accompanied by the economic ones: charity should fulfill the needs of the poor and not ferment laziness and all the vices that were associated to it, an especially important orientation when the lack of workers was almost dramatic. As king D. Duarte (1391-1438) said, «the life of men shall not be idle and the alms shall not be given to those who can work»" ${ }^{19}$.

The question of work was, in fact, a social matter of great importance and not only for economic reasons but also because of the organization and balance of society. The work was an obligation of the poor. It was their way of integrating the social order as it was drawn. The absence of work, forced by uncontrolled circumstances or by life option, led to social exclusion. This is the third point to bear in mind when we approach the poor relief and health care support and the legal documents that frame them.

The description of the beggar in permanent displacement as a stranger who tried to have access to community resources, without contributing to the local economy, and, in addition, as an agent of disorganization of the daily life, has an old history. Even if in the context of an economic crisis the authorities very often had the perception that the line between poverty and beggary was easily overcome and that it had to be taken into account. Socially unframed, parochial and family uprooted, the wage-earning worker was frequently at this borderline and the confraternities and the hospitals played, as it is well known, a relevant social role there.

Different, however, was the situation in the cases where the poor was a stranger to the community and showed its poverty through beggary. Except for the religious - a focus of permanent instability once the Franciscan and Dominican's clothes were used by the false poor to beg freely - the medieval communities did not peacefully accept outsiders. In the majority of situations they tended to be self-centred in what concerned charity, the reason why the shelters for pilgrims, which also lodged beggars and vagabonds, determined a stay usually no longer than three days.

\section{The Early Modern Legislation}

The demographic increase, the economic development and the social transformations registered, with prominence for the "urbanization" of the peasant, using

19 Livro $2^{\circ}$ dos Reis D. Duarte e D. Afonso $V$, doc. no8, fl. 8, in Humberto Baquero Moreno, Exilados, Marginais e Contestatários na Sociedade Portuguesa Medieval (Lisboa,1990), p. 57. 
Geremek's words ${ }^{20}$, in the open sense of the population movements from country to the city but also from the smallest centres to the bigger ones, would have to pull down the fragile "social balance" that was breached in each plague and famine outbreak, without forgetting the frequent wars. It was at this time that the interventions of the authorities tried to rationalize the poor relief, look for effectiveness in the way of work, thus, developing some specialization in terms of administrative rules and from then on, a growth in the punishment that also include the ones that were conniving with the vagabonds ${ }^{21}$. It is no surprise, therefore, to see them excluded from the hospitals, at the beginning of the 16th century, as ordered by D. Manuel I, on the 23rd of May of 1502, to the Évora municipality: the hospital was made for the sick and not for the beggars who could work ${ }^{22}$. The continuation of the regal politics to control beggary and, therefore, setting the universe of the deserving poor, would lead to the diploma of the 8th of July of 1500 that included the control of the beggars and the task of separating the true from the false poor in the competences of the new confraternities of the Misericórdia. The importance of this diploma does not come from the novelty of its content but from the fact that, for the first time, the crown gives to a charitable institution responsibilities that until then belonged to the political authorities, although the latter maintained the control of the roaming and the vagrancy that were linked to it. In 1521, at the end of D. Manuel I reign, times of epidemics, the king ordered a general inspection of the beggars that were invading Lisbon.

Among the various questions that he asked them before deciding on the begging licences, he identified, and made a compulsory register, of the beggars' geographic origin, civil state, economic situation and time of stay in the city ${ }^{23}$. The ones with curable illnesses were sent to the city general hospital, the Hospital de Todos-osSantos and the handicapped were obliged to learn a trade according to their capacities. If they refused, they could be given to whomever wanted to teach them. For

20 Bronislaw Geremek, "Mouvements hérétiques et déracinement social au bas Moyen Age», in Annales. Économies. Sociétés. Civilisations, 37e année -no 1, Janvier-Février, Paris, 1982, p. 188.

21 For Portugal, Humberto Baquero Moreno, Marginalidade e Conflitos Sociais em Portugal nos Séculos XIV e XV, pp. 24-60. Also, Rui Abreu Torres, «Mendicidade» e "Vadiagem», in Dicionário de História de Portugal (Joel Serrão dir.), respectively, vol. IV, pp. 254-255; vol. VI, pp. 239-240. For France, Michel Mollat, "Les problèmes de la Pauvreté", in Études sur l'Histoire de la Pauvreté, Michel Mollat (ed), Paris, 1974.

22 Arquivo Distrital de Évora (henceforth ADE), Livro I dos Originais, no 71, fl. 251. Cf. Humberto Baquero Moreno, Exilados, Marginais e Contestatários na Sociedade Portuguesa Medieval (Lisboa, 1990), pp. 59-60 and pp. 66-67.

23 The utopia of the questionnaire foresaw that his responsible tried to assure the truth of the poor statements by asking those who were from the same area. 
the robust and the non-authorized beggars, the usual treatment was punishment by permanent expulsion from the city and whipping ${ }^{24}$.

It is never too much, however, to detach that such a direct intervention of the Crown in the configuration of the concept of the deserving poor reflected and answered the fears of the populations, to its beliefs and suspicions, namely in relation to the foreigners, invaders of their daily lives. One of the particularities of these diplomas is the fact that they not only reflect the feelings and the attitudes of the dominant groups, but of the common people that make their voices heard in Courts and in this sense it is not an exaggeration to affirm that the legislation seems to reply to very specific social situations, not fiction, as many others, ideal realities that the legislator intended to implement. By doing so, they restricted, as it was seen, the access of some groups to the poor relief, at least to the institutionalized one. An element that would not suffer any alterations during the period analysed. If some changes occurred these were at the "ashamed poverty" level, whose social composition could vary according to the conjunctures. This means that when we analyze, in the long term perspective, the beneficiaries of the hospitals, conservatories or poor home relief, we do not find, except in very rare cases, any relevant social changes among the receptors. On the contrary, the conditions that allow, for example, those without work and the sick people to benefit from the home assistance, and, above all, the migrant workers, to the care of the hospitals, the young women and the widowers to profit from the subventions granted for the different institutions, remained. The decline of "the loose" charity in detriment of the direct donations for the institutions, reinforced after Trento, could have strengthened this trend without completely modifying $i^{25}$. Although other identical interventions in order to forbid and delimit beggary are known for different parts of Europe at the same time ${ }^{26}$, most of them came from the municipal authorities and were, therefore, circumscribed to specific geographical areas, although the English Statute of Labourers, from 1349, also had the aim of bonding labourers to the land.

By the beginning of the 16th century, when the Portuguese Crown created a nationwide network of brotherhoods, the so-called Misericórdias, aiming to harmonize the charitable and assistance practices, covering a large universe of poor, did not have any repercussions in the way the central power understood the concept of the "deserving poor". In other words, the widening of the "system" did not make it socially more inclusive. Beggars, vagabonds and the idle, not only continued, at least theoretically, excluded from the institutionalized poor relief organized by the Crown, as they also became a target of more repressive legislative measures.

24 ADE, Livro IV dos Originais, no 74, fls. 87-88v.

25 Ângela Barreto Xavier, "Amores e desamores pelos pobres", in Lusitania Sacra, 2a série, 11, 1999, p. 63.

26 Such as Nuremberg and Ypres, for instance. 
The panorama was common to the generality of Europe that, since 1520, went through an increase of repression and control exerted on the delinquents as well as a more active interference in the areas of the poor relief and health care. Related to the first case, the list traditionally presented - Nuremberg, 1522; Strasbourg and Leisning, 1523-24; Zurich, Mons and Ypres, 1525; Venice, 1527-28; Lyon, Rouen, Geneva, between 1531 and 1535; Paris, Madrid, Toledo and London, 1540, apart from the laws that emanated from the central power in the Netherlands, in 1531, England also in 1531 and in 1536; Brandenburg and Castile in 1540, France in 1536 and 1566 - was only incorrect by having omitted the Portuguese experience and it had, as was seen, deep roots in the medieval Law of the Sesmarias, even though touched by the Christian humanism of Erasmus and Juan Luis Vives. In fact, the charitable and social Portuguese politics defined in the first half of the 16th century equally congregates the three elements that Paul Slack, summarizing M. $\operatorname{Todd}^{27}$, identifies as the base of the thought and the humanist attitudes in relation to the poor relief: the Christian charity, the moral reform and the protagonist character of the public authorities' intervention in these areas ${ }^{28}$. The first one, based on the principle of the obligation of the wealthy in relation to the poor - now with other purposes, not only the soul salvation or the moral and social advantage of the donators - was spread in the Regiment of the Misericórdias, confraternities which were more devoted to the "public service" rather than to the brothers' self-help. The moral reform, so important for this humanism, and with it the defence of the work as structuring value of the society, comes to the Portuguese 16th century through the Law of the Sesmarias, that continues in force, then developed in unrealizable plans of action that identify and enumerate occupations for the handicapped ${ }^{29}$. The leading of these politics by the public authorities, the last of the three elements mentioned by Todd, was, as demonstrated, an old characteristic of the whole process, reinforced then by the new capacities that the central powers had of carrying out their social politics. Enough reasons, although there were still any doubts, to place the reforms done in Portugal by the ones carried through in Germany, France and England ${ }^{30}$.

The reasons for such an "intervention", in Portugal as everywhere, have to be found in the economic crisis that Europe was going through but also in the emergent political power expressions: the ones of the Early Modern State, trying to be more efficient and more present than ever. Vagrancy did not facilitate the control

27 M. Todd, Christian Humanism and the Puritan Social Order, Cambridge, 1987.

28 Paul Slack, The English poor law, pp. 6-7.

29 The emphasis on the handicapped is a substantial difference in relation to the English laws promulgated at that time. Cf. Paul Slack, The English poor law, 1531-1782, p. 9.

30 We claim for Portugal the same "statute" that Paul Slack demanded for England when he comparatively analysed the English case with the ones of France and Germany. Cf. Paul Slack, Paul Slack, Poverty and Policy in Tudor rand Stuart England, p. 23, p. 116, pp. 119-121. 
neither of space nor of people and were a threat for cities and villages. With no fixed residence, there were no men to fight or to pay taxes. And the royal authority, which had already imposed the military and tributary measures with difficulty to the stable population, was more hindered by the wanderers.

After the letter of D. Manuel I of 1520, two diplomas emanating from D. João III government need to be highlighted: one from 1538 and another one from 1544. In both cases the effectiveness in the application of the laws, especially in relation to the city of Lisbon, was the central question. Continuing the Law of the Sesmarias, the law of 1538 severely penalizes idleness.

The decisions concerning beggars promulgated by D. João III in 1538 - the King who was responsible for the first general account of the Portuguese population (Numeramento de 1527) - were not so different from those listed in the Law of the Sesmarias, but they were more rigorous in order to make them more effective ${ }^{31}$. Thus, they were followed by an increase in the punitive powers of the royal police, especially in Lisbon ${ }^{32}$, where a crowd of Portuguese and foreign vagrants remained, refusing to work and "becoming thieves and getting into other bad habits", even if the latter were forbidden to enter the kingdom ${ }^{33}$.

The penalties assigned for the impostors were clear: if the beggar was a slave and begged with the consent of his owner, this one lost his right of property that would pass to whoever denounced the situation. If he acted without the proprietor's agreement, the beggar would be publicly beaten. In the case of a free man who dissimulated illness, he should serve the denouncer for five years, only having the right to be fed and clothed. Finally, his owner could negotiate the beggar as he pleased ${ }^{34}$. In short, a very violent law if compared with the 1547 English one, at least in terms of time once it imposed two years of slavery to the vagabonds. Not in terms of penalties as the English 30's laws already imposed measures of mutilation for those who offended for a second or third time ${ }^{35}$.

Still more daring and complete - a probable evidence that the previous document would not have produced the desired effect - would be the law of the 4th

31 Duarte Nunes do Lião, Leis Extravagantes e Reportório das Ordenaçôes (Lisboa, 1987), pp. $154-155$.

32 Idem, ibidem, p. 32. (Also, Eduardo Freire de Oliveira, Elementos para a História do Município de Lisboa, tome I (Lisboa, 1889), pp. 545-546).

33 Duarte Nunes do Lião, op. cit., p. 155. The same law that gave foreigners 20 days in order to leave the place in which they had been caught and 30 days to leave the kingdom.

34 Less strict was the law for the sick owners, only forced to pay 5000 reais to those who found them begging. Cf. Duarte Nunes do Lião, op. cit., 4th part, title XIII, law 1, pp. 154v.155 .

35 In England the law was not efficient and probably the same occurred in Portugal. Cf. Paul Slack, The English poor law, 1531-1782, p. 10). A detailed analyses of this law can be found in C. S. L. Davies, "Slavery and protector Somerset; The Vagrancy Act of 1547", in The Economic History Review, New Series, vol. 19, no 3 (1966), pp. 533-549. 
November of $1544^{36}$. Four years after the cardinal Tavera, in Castile, had promulgated the law that recuperated the restrictive legislation of D. João I (1387), adapting it to the circumstances of the time, the Portuguese monarch congregated some disperse laws creating a sort of "Regiment of the Beggars", later identified by D. Sebastião as the "Law of the vagrants". It started being applied in the places where the King was but in 1558 it was extended to the whole country. Summarizing a very long document, its content can be organized in two great lines of intervention. The first one dedicated to the punishment and another one that identifies the parameters to be respected in the concession of begging licenses.

Punishment appears in a cumulative hierarchy and is described in a clear and simple way: when offenders were arrested for the first time, they should be imprisoned, publicly flogged and expelled from the place where they had been caught. The second time, they would be expelled from the kingdom. The third time, Brazil would be their destiny for a period of 10 years. The loss of personal belongings, if they had any, as well as imprisonment and flogging were inherent to each of those punishments.

A little more complex was the process leading to the issuing of authorisations to beg. The model was still the medieval one developing two rather old and interdependent topics: the restriction of the number of beggars, even in the case of the physically handicapped poor, and the incentive to the self-supportiveness by means of work.

Those who had any properties or a trade, even if ill or lame - including the blind - were automatically excluded from getting licenses. All the other cases should be analysed one by one. And the indications were clear: those who had problems with their feet would be taught the trade of goldsmith, shoemaker or the like. Those whose handicap affected their hands would have to try a way of life with religious institutions. The blind would have to be taught the trade of "smiths or blacksmiths, in order to work the bellows". Within this context of restrictions, the poor who had curable diseases - therefore temporarily handicapped - should be sent to hospital and not allowed to expose their disability. To sum up, the main objective was to seek for any compatible activity for every potential beggary, involving the authorities in charge of setting them on the right track. To fight against idleness and the evil it might cause, was a priority and the pedagogy of the work, already found in the Law of the Sesmarias, and afterwards defended by Jean Luis Vives and Cristóbal Herrera many years later, is clearly stated here, but the social awareness was also extended to the children. The beggars were now only allowed to move about accompanied by their own siblings (except in the case of the blind) but only until they were 9 years old. In the other situations, they had to hand over the children to

36 Duarte Nunes do Lião, op. cit., law 3, pp. 155-157, (decree of the 4th of November of 1544). 
the partner who did not have a license to beg (which presupposed that there were no couples among the beggars), under the threat of losing them. Finally, all licenses to beg lasted only a year, and after that period each situation was re-evaluated. To the restricted group of those authorized to beg, the license would only be granted after presenting a certificate guaranteeing that they had confessed. Not being familiar with the Our-Father and the Creed were conditions for the refusal of new licenses. The high degree of bureaucratization and control of the process still demanded the existence of a specific writing - already foreseen in the diploma of 1520 - that registered all the data that identified the beggar: name, age, dwelling, birthplace, disease or cause that could justify the license. It must be mentioned, however, that in no circumstance would it be possible to grant licenses to foreigners, even in the case of obvious necessity or "acceptable" justification. A usual procedure at the time, that Cordova, like other Castilian cities, had already been practising since the $1520 \mathrm{~s}^{37}$.

Really important was the fact that the diffusion of the information was made through the beggars - ten or twelve would be called making them responsible for spreading it - and the strong incentive to the population to denounce everybody that did not fulfill the rules established in the law. Nevertheless, not only restrictions were registered in the diploma of 1544: the brotherhood of the court, in charge of the implementation of these measures, would have to provide installations - illuminated and warm - where the authorized beggars could spend the night, if they so wished.

The search for the efficiency of the mentioned measures was followed by the reinforcement of the policy action of the regal officers, above all in relation to the capital, where to the Portuguese loafers joined the foreigners, including gypsies ${ }^{38}$, except in the cases where they had a skill and wanted to make use of $\mathrm{it}^{39}$. Less than three months later, a new regal order obliged an inspection every six months to "the loafers without work" that were roaming in Lisbon, arresting and proceeding against them according to the Ordinances ${ }^{40}$. Once again, the monarch acted, as stated by the diploma, answering the request of the people, in this case the ones represented in the courts of Almeirim of 1544, that inclusively suggested an immediate banishment of the transgressors to Brazil ${ }^{41}$.

37 Linda Martz, op. cit., pp. 14-15.

38 Duarte Nunes do Lião, op. cit, 4th part, title XIII, lei II, p. 155, (law 24 from the Courts of 1538).

39 In 1563, the 14th of August decree defined foreigners: anyone who looked like, dressed and spoke like an Armenian, Greek, Arabian, Persian or any other nation under Turkey. (Idem, Ibidem, law V, p. 158v).

40 Idem, Ibidem, 1st part, title X, law III, p. 32, (decree of the 1st of February of 1545).

41 Eduardo Freire de Oliveira, op. cit., tome I, p. 546, note 1. 
Whether through regal initiative or through the pressure of the populations, it was certain that more and more was demanded of the judicial officials, whose repressive competencies were gradually widened ${ }^{42}$. In 1544 the central government recuperated the Law of the Sesmarias' idea that foresaw the existence of a net of employees and informers who (now) had to watch the quarters, each of the beggars and all the places that could receive vagrants and foreigners ${ }^{43}$.

The social pressure that the big cities, and specifically Lisbon, suffered with the migratory waves that arrived in crisis conjunctures justified, in part, the aggravation of the overwhelming measures against "the beggars and the vagabonds". According to the regal letter of the 30th of March of 1546, the young men from Beira and Alentejo flocked to the capital, refusing to work, wandering meaningless, ending up, very often in jail, burdening the confraternity of Misericórdia with feeding and release expenses ${ }^{44}$.

So, as the Law of the Sesmarias had been the source for the social politics developed in the following two hundred years, this "Beggars' Law" would be the guide for the future. Neither the philosophy nor the principles would be changed. In fact, from the late Medieval Ages until the end of the 18th century the discourse of the laws only introduced a few alterations accompanying the social and economic evolution. In the 14th century as in the 18th century, beggary, vagrancy and crime were synonyms, both for political powers and for society in general. It can be said that the repetition of the same laws, year after year, proves its inefficiency, but it also testifies the permanency of the values considered to be the basis for the good functioning of society, such as work, for instance. When we analyse the 1544 law and the tasks proposed for the handicapped, this is quite obvious. The main question was to maintain people occupied with a job and to assure that everybody had an "honest" way of earning his/her life.

The same happened with the condemnation of the nomadic life. Since the old Law of the Sesmarias the monarchy dreamt of a system to gather the information in order to promptly act in the case of those who refused to work, opting for begging and vagrancy. In the Early Modern Period this control was based on a network of officers and informers that, in the different districts, watched people and the houses that might shelter the wanderers, the prostitutes and the non working foreigners, the latter, more and more controlled by the authorities ${ }^{45}$. If the defence of public health and public order was the main argument used, the persecution of the vagrants was the way found to deal with the problem. Neighbourhood dilation,

42 Idem, Ibidem, pp. 545-546, (30th of Março of 1546). (Also Duarte Nunes do Lião, op. cit., 4th part, title XIII, law IV, p. 157-158v, (letter of the 6th of November of 1558).

43 Eduardo Freire de Oliveira, op. cit., tome III, pp. 69-70.

44 Idem, ibidem, tome I, pp. 545-546.

45 Idem, ibidem, tome III, pp. 69-70. See also the law of the 9th of March of 1641 in Colleç̧ão chronológica da legislação portugueza, 1845-1859, p. 76. 
urban militias and the rise of the salaries of the people involved in the execution of these laws - such as the prison guards - became the strategic factors of the whole system.

\section{The Romany Question}

It was in this specific social-economic context that the crown politics related with the Roma were developed. It is not possible to ascertain the exact date of the arrival of the gypsies in Western Europe, but it is more than probable that it might have taken place early in the 15 th century, spreading all over Europe since $1417^{46}$. From the beginning of the following century, there was an increase in the number of laws exiling and condemning them to the galleys. These documents have provided grounds for the thesis that they were subjected to ethnic oppression as soon as they stepped on European soil. The long tradition of social marginalization against the Jews and the Moorish justifies the studies that viewed the persecution of gypsies as the result of a new movement of intolerance. However, these studies have forgotten to take the context into account, namely, its historical framework: in this case the one of a Europe involved in violent fights against the nomadic life that the official discourses named as vagabondage and vagrancy. Portugal, like Spain, France or England, only to refer some examples ${ }^{47}$, was legislating since the 14 th century against the false beggars, people who refused to work even if they could, preferring idleness and the absence of social obligations. Living as vagrants, the gypsies were punished as such. The social stigmatization against the lifestyle that characterized them was already constructed when they arrived in Europe. What happened then was, therefore, a process of aggregation and not of construction of a new concept ${ }^{48}$.

In the case of Portugal, what is relevant is the briskness of how the political discourse considered first gypsies as a new group of vagrants and then as a sort of reference of a specific lifestyle and as a specific cultural feature. The absence of specific punishments promulgated for the gypsies should be highlighted. In fact, the same ones imposed on false beggars and idle people were applied to them. The sentence

46 According to Bernard Leblon, "Les Gitans dans la Péninsule Ibérique", IN Études Tsiganes. Bulletin de l'Assiciation des Etudes Tsiganes, 10e annee, nos 1 et 2, Mars-Juin, 1964, pp. 1-24 e no 3, Octobre, 1964, pp. 1-28. See also, Angus Fraser, 1992. Quoted by Karina Bates, "A brief history of the Roma", SCA Home Page.

47 H. T. Crofton, "Early Annals of the Gypsies in England", in Journal of the Gypsy Lore Society, 1, 1888/89 and F. de Vaux de Foletier, Les Tsiganes dans l'ancienne France, 1961.

48 Take out the laws from their context, or extract from a general law against beggars and vagabonds only the orientations related to the gypsies and refer those laws as if they were specific of the gypsies, as suggested Bernard Leblon (Idem, Ibidem, nos 1 et 2), creates another reality that doesn't exactly correspond to the historic reality. 
used in the laws enlarging the population of vagrants to "those who live like gypsies", shows that they are seen as the archetypal unacceptable lifestyle. It was assumed that the vagrants' way of life was as an intrinsic characteristic of the gypsies and it signifies the rejection of the principles that the society had identified as essential elements for its functioning: a settling place for the family in the countryside or in a city. The radicalization of the official discourse - not of the severity of the punishment - would occur when the authorities understood that the gypsies' way of life was not a transitory state of foreign newcomers but a long lasting one. From then on the exiles were justified with the purpose of the group extinction.

What is the more detailed analysis of this history? Having probably entered Portugal during the last decades of the 15 th century, the first literary ${ }^{49}$ and legislative references of gypsies appeared in the 1520s. During the early modern period, the relationship between the Portuguese society and authorities with this group of newcomers can be divided in three different periods.

The first one coincides, roughly, with the reign of João III (1521-1557). It was the beginning of the process and it is quiet obvious that the question of the gypsies did not detach itself from the problem of false beggars and vagrants. The first decree known, from the 13th of March $1526^{50}$, forbidding the entrance of gypsies into the kingdom and ordering those who already lived there to leave, is justified by the monarch's need to guarantee public order. This is the same argument used in the laws that were promulgated against idle people and foreigners in general. Of the population complaints against gypsies, only the reference to "so many spells that they pretend to know, which cause people so much loss and trouble" ${ }^{\text {"1 }}$ stands out from those received by the King against the vagrants since the 14th century. The proceeding law, issued in 1538, which preceded and laid the grounds for the aforementioned "Beggars Law", didn't alter the root of the question in spite of the specification that it concerned both false beggars and gypsies, and also for "other people from any other nation wandering about or living like gypsies" ${ }^{2}$. But, although in a subtle way, it shows that the legislator had recognised nomadic life as the typical way of life of the gypsies, and to this, the common people had long ago associated an ensemble of activities that they considered perverted the order of their everyday life. From that moment on, all the mandates condemning wandering and idleness would equally have as a target "those that lived like gypsies".

49 Gil Vicente, Farsa das Ciganas, 1521 or 1525.

50 The non identification of the sources where Bernard Leblon gathered the information does not allow us to confirm several of the laws referred. For example, when he mentions that «A la suite d'une intervention des Cortés, Jean III décrète l'expulsion des Gitans» (op. cit., p. 15), it is probable that he is implying only to a discussion occurred in the Courts and not to a law that is from the following year.

51 Joel Serrão, op. cit., vol. II, p. 69.

52 Duarte Nunes do Lião, op. cit., p. 155. 
During the second phase - which basically extends throughout the second half of the 16th century - it is the religious side of the question that stands out, though the aforementioned assumptions do not change. The main point was then the expansion of the Ottoman Empire, trying to conquer Europe under the orders of Suleiman, the Magnificent. Around the Pope, the Holy League intended to combat the "unfaithful" and Spain became the protagonist in the fight against Islam. In 1571, the Battle of Lepante, was considered the most important victory of Christianity ever since the conquest of Granada, back in 1492 .

Thus, it is easy to understand why the law issued on the 14th of August 1563, condemning false beggary and idleness, specified that anyone coming from Armenia, Greece, Arabia, Persia "or other nations under Turkish rule" would not be authorised to enter the kingdom ${ }^{53}$. To these, the one from 1604 would include "the Moorish from Granada". A detail that can reflect the Spanish kings' apprehension (by that time also kings of Portugal) before the possibility of a Moorish insurrection synchronized with a Turkish invasion, in the sequence of the rebellion against the Christians of Granada (1565).

In both diplomas, 1563 and 1604, the gypsies were present. Besides this, Pope Pius V, in his bull of 1568, had banned them from the lands of the Catholic Church. Coming from the lands under Turkish rule, gypsies were now considered a potential religious problem. The deportation of gypsies to the colonies ordered by Spain, France and Portugal at that time must be situated in the context of the crusade against Islam that threatened the Mediterranean. Yet, the religious situation did not overshadow the social question: the reference to the Portuguese beggars that lived like gypsies in the above documents shows that roving and the associated lifestyle continued to be a central concern. Further, because the situation of economic depression, increased by successive outbreaks of the plague since 1570 , raised the fear of the population, who felt more and more fragile. In this sense, the 28th of August 1592 law, that gives the gypsies four months to leave Portugal or settle down in one place, banning them from living in groups or clans, under penalty of death, is already the prelude of the last phase previously referred to. Even though the religious reasons did not lose importance, they were not suggested any more after that. In the future, the law, as well as the population, would be divided into periods of violent repression against gypsies and of their social integration. The scene was of the hardening of the laws against the vagrants and beggars, when the settlement of people became almost a legislative obsession. One after the other, the diplomas repeated that those who wandered about without work, gypsies or not, could not do it for more than twenty days and even beggars with licences were only authorized to beg in their places of origin or areas of residence, not exceeding twenty leagues. Wanting to leave, they would have to be submitted to the

53 Idem, ibidem, p. 158v. 
municipal inspection. The identification of the companions of the blind or crippled continued to be obligatory, the law determining that that function could only be done by people of the same sex, opening an exception for the women, authorized to have the company of their children, as long as they were not older than fourteen.

It was not only the restriction to the beggary that became more pressed but also the penalties became more deterrent: those who were caught infringing the law for the first time would be beaten and banished for one year from the place where they were begging. The second time, apart from being whipped, they would be banished for one year to Africa. The third time they were banished to Brazil for 5 years. In the case of the foreigners, they had 20 days since the publication of the regal diploma to abandon the place where they were captured, and should leave the kingdom within 30 days. If they were caught again they would suffer the penalties foreseen for the natives, except if they had a profession and wanted to exercise it - a common determination in this type of legislation.

Meanwhile the measures of policing the spaces and the populations multiplied somewhat all over the country. The justices were ordered to inspect the inns and hospitals every fortnight, checking if the above mentioned people were lodged there. If so, their arrest could be done only based on oral testimonies certifying that they were begging or roaming ${ }^{54}$. The objective was, obviously, the simplification of administrative and judicial procedures so that the processes could run quicker.

New data to consider in this context is the intervention of the local powers, precisely since the conjuncture of crisis of the end of the 16th century, trying to find some balance between the general guidelines emanated from the crown and the need to face specific social situations. It does not mean that the local authorities were more sensible and tolerant with beggars and vagabonds. But it is quiet clear that the perceptions of the acute crises could push people to beggary that otherwise would not be there and it was in this direction that some authorities acted while the crown strengthened its repressive politics, as it occurred, for example, in the 1604 diploma.

Entitled On the poor that are begging (Sobre os pobres que ande pedir ${ }^{55}$ ), the text starts as almost all those that had preceded it: although the Ordinances determine the procedures to follow against those who begged without the respective licenses, their number was increasing without any control ${ }^{56}$. The conjuncture imposed even more efficient and restrictive measures. The total prohibition of the beggary without license was reaffirmed but its control was taken from the local authorities. The

54 Duarte Nunes do Lião, op. cit., $4^{\text {th }}$ part, title XIII, law IV, pp. 157-158v, (letter of the 6th of November of 1558).

55 Biblioteca Pública de Évora, cod. CXIX/1-13, fls.64-65v.

56 For Portugal there isn't a list organized for the English $16^{\text {th }}$ century as the one presented by A. L. Beier in "Vagrants and the Social Order in Elizabethan England", in Past and Present, nr. 64 (Aug. 1974), pp. 3-29. 
central government officials, or the landlord ones, would be responsible for the examination of the candidates for a beggary license. The poor should previously be informed of the day and place for the public exam. Only the blind, the crippled and the old, unable to work, could receive permission to beg, but restricted to six months and only to be used in the places where they were granted. After this time, the certificate could be renewed, after an evaluation of each case. Whoever did not have the license eight days after the announcement of the public examination and continued begging would be imprisoned. The punishment, based on a short proceeding, followed all the common procedures, but for the first time severe punishments were foreseen for the authorities that did not correctly abide with their professional obligations.

Summarizing, at the beginning of the 17th century the Crown took on the competency to control beggary and the licences attribution again, as it was foreseen in the Law of the Sesmarias; the licences' validity time was reduced from one year to six months and, finally, the non efficient justice officers were penalized. Once again the chronological coincidence between the English law of 1598 and the Portuguese one from 1604 must be highlighted. Neither religion nor the distance caused any difference in terms of objectives and procedures. Only the option for the coordination of the processes, in Portugal under the control of the central power, introduced a dissonant note ${ }^{57}$.

Abreast with these alterations, the ongoing justice reform redistributed, in Lisbon, the monitoring of the quarters for a better control of undesirables, among them, beggars. Point 13 of the new regulation specified that judges should be aware of who begged in their area of control, proceeding against them if they did not have a license respecting the orientations of the diploma of the 9th of January of $1604^{58}$. They should also inspect the ones that begged for the Church, certifying if they had the necessary authorizations, but also their way of life, if they had a skill and did not use it because they preferred to beg, and if they used the alms collected for their own benefit. But also not neglecting the control and visits to "gambling houses and other parts where vagrants used to be", arresting the transgressors and banishing them to India ${ }^{59}$.

Reinforcement of policing and control, obviously, also reached the gypsies. However, when analyzed in detail, the diplomas that in this conjuncture had been promulgated do not differ substantially from the ones that the Regiment of the Beggars stipulates, in 1544, for those who insisted on begging without a license. What makes the two social situations different now (beggars and idle people "who

57 Paul Slack, The English poor law, 1531-1782, pp. 52-53.

58 Colleç̧ão Chronologica de Leis Extravagantes posteriores á nova compilação do reino das Ordenaçôes do Reino, publicadas em 1603, tome I (Coimbra, 1819), pp. 87-100.

59 Except if they were skilled mechanics, once they should stay in the kingdom. Cf. José Justino de Andrade e Silva, op. cit, 1640-1647, p. 76. 
lived like gypsies" and the gypsies themselves) - is the fact that the authorities assumed that the latter had very tight solidarities, able to protect them and, consequently, that they should be more controlled. Control that had to be extended to some royal officials, who used to provide them with false residence permits, allowing them to stay in the country even though they lacked a stable address ${ }^{60}$.

Recognizing that the previous punishments had been insufficient to make them leave Portugal or to change their way of life, the law issued in 1606 wanted to make the expulsion effective immediately after the first imprisonment, increasing the number of years they should be kept out of Portugal on an increasing basis after each detention: from three years for the first time to six years if the person was arrested for the second time, and ten years the third time. The monarch appealed for the quick intervention of justice because, as he wrote, it was necessary "for the welfare and tranquillity of my vassals and my kingdom". Yet, only approximately eight years later, did he order the cancellation of residence permits for gypsies.

This was, in fact, a rather controversial situation that the monarchy seemed to manage without following a specific line of conduct, or, at least, seeming it wanted to integrate the gypsies, whereas they systematically rejected it as they did not accept the constraints it imposed on their mobility and actions. In this regard, we should bear in mind that the aforementioned law of 1594 that condemned them to death also gave them four months to settle down in a stable residence. A threat that did not seem to obtain any results, as attested in a royal letter dated the 28th of March 1618 that orders the authorities to take a census of the gypsies who moved about the kingdom "in different attire and speaking differently from nationals". Once again, the gypsies proved to have been strong enough to face the authorities, and it would not be the last time.

Another proof that the question of gypsies was far from being reduced to an ethnic matter can be found in the last Spanish mandate, when the reigning princess claims that "being a gypsy does not consist in the birth, but in living like one". The convicted that filled the galleys that were anchored in the river Tagus in 1639, after a fast court trial in order to facilitate their shipment, were in fact gypsies but also those who lived like them ${ }^{61}$. The uncontrolled mobility and the refusal to work were still the greatest hindrances to social integration and the main complaints presented by the communities.

It is not possible to know how many people were sent to exile in 1639 and how many of them were gypsies ${ }^{62}$. Documents of 1647 refer to the relatively-recent general persecution of "vagrants called gypsies that move about in clans, living off rob-

60 Collecção Chronologica de Leis Extravagantes posteriores á nova compilação do reino das Ordenaçôes, cit, tome I, pp. 62-64, entitled Alvará em que se accrescentarão as penas contra os ciganos que forem achados neste reino.

61 Collecção chronológica da legislação portugueza, p. 193.

62 Idem, ibidem, pp. 332-333. 
bery, deceit and lies". Although this document mentions, for the first time, that the objective was to do away with "idle people, who did not have a stable residence, a house of their own or a job", it equally informs that ten gypsy families were kept in one of the Lisbon prisons because their chiefs were considered to be too "old and unable" to make such long travels. The conditions that were imposed on them in order to allow their stay were not different from those imposed on other minorities before, and had already been repeated manifold: settling down in a place, in this case, in the centre of the country ${ }^{63}$; find a job and abandon the features that identified their ethnic background - language, attire, sorcery, animal commerce and, as documents added, "their manners and lies". The innovation of the 1647 law was related to gypsy children who had to be handed over to the institutions in charge of the upbringing of the abandoned children at the age of 9. That is to say, the Misericórdias and the orphan colleges: institutions that prepared - or should prepare - the children for the working market, instilling the basic values of Christianity in them. For the first time in the case of the gypsies the law assumed pedagogy as a form of repression and integration ${ }^{64}$. Thus, once more, they were considered at the same level as the beggars that dragged their children about with them illegally, contravening the specifications of the law issued in $1544^{65}$.

The social and even the political aims that such measures intended to bring about are easy to understand. Especially, if we take into account the context where they were placed: a country that was going through a crisis after the restoration of its independence, under an atmosphere of social distress as a result of economic difficulties, worsened by the increase of taxes - so criticised during the Spanish rule and that explains, for example, the decisions taken in Court, in 1654, when people complained about gypsies "and other mobs of nationals that used to hang around with them", impelling the King to allow house raids in order to identify those who lacked residence permits. This time, as before, the plaintiffs received an affirmative answer from the political power: "because what they propose is provided for by the general law, being utterly fair and convenient" ${ }^{36}$. Some of the gypsies caught during these actions were expelled to Cabo Verde, S. Tomé, Cabinda, Quicombo, Mossamedes and Maranhão, in $1686^{67}$, or to Baía, in $1718^{68}$.

63 Collecção chronológica da legislação portugueza, diploma from the 21 st of October of 1647.

64 From this diploma on, this determination would be repeated in all the following ones.

65 Colleç̧ão chronológica da legislação portugueza, p. 11.

66 According to a report handed over to the people of Pombal (Collecção chronológica da legislação portugueza, pp. 219-222).

67 Collecção Chronologica de Leis Extravagantes posteriores á nova compilação do reino das Ordenaçôes do Reino, publicadas em 1603, tome II (Coimbra, 1819), pp. 364-366, 10th of November of 1708.

68 Like Spain and France did more or less at the same time. 
The restlessness that Portugal was facing generated a growth in violence of state officials. Reformed in the first decades of the 17 th century, the judicial system multiplied the number of police agents and increased their power. The recurrent references to the saturation of prisons and the need to accelerate judgements to facilitate the expulsion of the criminals are, among others, good indicators of the efficiency of the measures taken.

Social "normalization" was, in this context, a priority for the authorities. Those who wanted to be part of society but without losing their autonomy had, obviously, very little room, but this did not mean that the State did not use the minorities, in this case the gypsies, guaranteeing them protection whenever convenient for its interests. The evidences of this behaviour are multiple. For example, "more than two hundred and fifty gypsies", that were "defending", according to the documents, the borders with Spain after $1640^{69}$. They were probably more like informants rather than soldiers, but still serving the King. The same reason, presumably, that justified the order sent by the monarch to the Évora municipality, in 1699, forcing it to accept several gypsy families that were moving from Lisbon - due to the high cost of living, as they complained. Acting in this way, not only did the monarch contradict the decisions of the local power - forbidding gypsies in the city - as he advised the authorities that the gypsies should not be molested, instead, the rights that he, the King, "used to bestow on them" ${ }^{70}$, had to be respected. Not far from Évora, in Elvas - a Portuguese city at the Spanish border - the population complained that every time there was a new repressive wave in Spain it was invaded by hoards of gypsies ${ }^{71}$.

To sum up, when analysed in a long term perspective, the relationship of the Portuguese society and the political powers with the gypsies ran under this contradiction and apparent conflict of interest. The latter, territorializing, momentarily, the places they went through, reproducing and perpetuating their lifestyle, showing that their social memory was deeply rooted being able to resist the values that were not theirs. For instance, values concerning work and sedentary habits that the authorities and the main part of society considered to be structural elements of public tranquillity and social stability ${ }^{72}$. The authorities proclaiming the conditions for the social assimilation of gypsies: "they should not use their attire and their language; not occupy more than two houses in each street; not walk together in the streets; not camp next to the roads or in the fields; not sell, buy or exchange ani-

69 Collecção Chronologica de Leis Extravagantes posteriores á nova compilação do reino das Ordenaçôes do Reino, publicadas em 1603, tome I, I, pp. 524-526.

70 Arquivo Distrital de Évora, letter from the 30th of July of 1699.

71 Bernard Leblon mentions several riots of the populations and an intensive municipal legislative activity against the gypsies that were arriving in the city.

72 Collecção chronológica da legislação portugueza, 1845-1859, pp. 26-27. 
mals; instead they should assimilate the customs of the country and leave aside their own customs".

All the historical evidence presented here prove that the gypsy question is, also, a cultural question, the reason why we second Daniel Chirot's opinion ${ }^{73}$ : the States did not create the category of "gypsy". On the contrary, the gypsies appeared in Europe when the political authorities were developing strict measures against wandering and vagrancy. Living like idle people, they were punished as such. Expecting society to accept the difference, differentiating between born nationals who refused to obey the rules and live according to the established values, and the newcomers whose lifestyle consisted of permanent wandering, is an anachronistic exercise of little historical rigour. In a society where false beggars were flogged and expelled to the colonies, taking away their children; where robbers' hands were cut off; where prisoners were branded in order to identify them as criminals more easily, to defend that the violence against gypsies was, from the beginning, a result of ethnic persecution does not have historical support. The victimization discourse should not be applied for the period under analysis. Statements such as the one by C. R. Boxer, blaming king João V (1700-1750) for his "obsessive hatred" against gypsies ${ }^{74}$, or that "it was in this particular respect that the trans-Atlantic shipment of the Africans differed from that of the gypsies: the former were transported for economic reasons; the latter, for reasons of hate ${ }^{75 \%}$, imply a rather misunderstanding of the Early Modern period.

\section{Final Considerations}

What is surprising in the analysis of the legislation against beggary and vagrancy, Romany or not, is the almost silence of the 18th century. Only interrupted in the context of the 1755 Earthquake, by the diploma of the 4th of November, that restrained and condemned the vagabonds and beggars who could work, and later, by the General Intendancy of the Policy, created on the 25th of June of 1760, with competencies for the repression of the same groups and for the concession of begging licenses. However, neither in one case nor the other are there novelties to be

73 Presented in the review of the book of Chirot, Daniel "Gypsies and Other Itinerant Groups: A Socio-Historical Approach", in Journal of Interdisciplinary History - Volume 30, Number 2, 1999, pp. 306-308.

74 C. R. Boxer, O império colonial português (1415-1825) (Lisboa, 1981), p. 299.

75 Cf. Ian F. Hancock, The Pariah Syndrome: An account of Gypsy slavery and persecution, Download the full text of the web version of The Pariah Syndrome, cap. VII. Treatment Elsewhere in Europe: Spain, Portugal and France http://www.geocities.com/Paris/ 5121/pariah-ch7.htm. 
registered $^{76}$. How do we explain this situation? More tolerance from the authorities, precisely when in countries like France more repressive mechanisms of control were created $^{77}$ ? More condescension of the populations, conscientious, also, of their own vulnerability?

When the crown opted to control the whole legislative process of repression of beggary and vagrancy, excluding these groups from the institutional support, it revealed, probably, too confident in its capacities, the officials that could spread and execute its orders were scarce. On the other hand, when it tried to uniform the charity and the assistance practices, the crown forgot the local specificities and priorities, namely in terms of the management of the available resources. It does not mean, however, that the laws were unknown or that they did not produce any effect. The (few) existing lists of poor that benefited from the Misericórdias' support do not include beggars, vagrants or gypsies and these are rarely found in the most open and less selective institutions of charity and assistance that existed in Portugal in the Early Modern Period: the hospitals. Could the hospitalized people defraud the authorities presenting false identities? No doubt about it. The most probable hypothesis is that a considerable number of beggars and vagabonds presented in the hospitals as workers, benefiting, thus, from the resources of institutions that should not shelter them, or, in other words, the social uses of the "system" and the permeability that characterized it cannot be forgotten. But vigilance existed and this explains, for example, the creation of alternative institutions to receive the poor that were not sick; in one way or another, the measures of social control had been spreading and had practical repercussions in terms of the people assisted in the institutions under the crown tutelage.

The silence of the Church in this process should also be highlighted, at least when compared with other European examples where identical measures created a climate of animosity and serious public discussions. The net of Misericórdias spread all over the country exerted, in fact, a charity based on the Christian principles but it was far from being a socially inclusive charity. Their prisoners, their poor, their sick, their ashamed poor, were, at least theoretically, citizens selected according to their moral positions, their work capacities and their real necessities. It is true that beggary was not completely forbidden but, in the laws, it was limited and subjected to a bureaucratic process of some complexity and one should be reminded that those laws were responsible for the raids that, in the 17th century, took place in the whole country, arresting and banishing the transgressors to the colonies. In contrast to what happened in Ypres and Castile in the 30s of the 16th century (and again in

76 Once again Bernard Leblon presents the laws that makes the gypsies work in the public works as if they were only made for them.

77 Olwen Hufton, Begging, vagrancy, vagabondage and the law: na aspect of the problem of poverty in Eighteenth century France», European Studies Review, 2, 1972, and from the same author, The Poor of Eighteenth-Century France. 1750-1789 (Oxford, 1974), pp. 219-244. 
Castile after 1565), Portugal did not register legislative retreats in this area. The principles that guided the practices of charity and of institutionalized assistance were the ones of Jean Luis Vives, Inácio de Loiola and, inclusively, of Lutero and other protestant reformers severely criticized by the Catholic Church and even if some theologians defended poverty and the compulsoriness of the alms, the ones that also defended a positive discrimination, according to age, work capacity and moral behaviour were in greater number. If the information concerning how the local authorities reacted to the central power orientations is scarce, it is not presumable that they have contested them: there is too much evidence showing them trying to escape from the expenses with the prisoners, foundlings and poor in general. Believing in the petitions presented in courts, the people's representatives had also not modified their attitudes towards the beggars. On the contrary, they were frequently requesting an aggravation of their criminal punishment. Before the law and the will of the citizens, the capacity of maneuver of the false poor did not seem to be too much. The reality could have, obviously, been different but not the one that appealed to the institutionalized charity. In fact, it is the perception of the limited quantitative expression that this type of assistance had that obliges a re-evaluation of the informal mechanisms of support, namely, the casual alms determined in the wills or the ones given at the entrances of the religious institutions, still of less documentary memories. To give continued to be one of the most important moral virtues, independently of how it was done and its social repercussions cannot be underestimated. As should also not be the competencies and the capacities of the Early Modern monarchs in terms of social discipline, poor relief, health and welfare politics. Even taking the social and political specificities where they were exerted into consideration.

Laurinda Abreu, PhD, is Professor at the Department of History, Évora University, Évora, Portugal. E-mail address: laurinda.abreu@mail.telepac.pt. 


\section{References}

Abreu, Laurinda, Janos Sandor (ed.), Monitoring health status and vulnerable groups in Europe: past and present, Santiago de Compostela, 2006.

Beier, A. L., "Vagrants and the Social Order in Elizabethan England", in Past and Present, nr. 64 (Aug. 1974), pp. 3-29.

Boxer, C. R., O império colonial português (1415-1825), Lisboa, 1981.

Coelho, Maria Helena da Cruz, "As confrarias medievais portuguesas: espaços de solidariedade na vida e na morte," in Cofradías, grémios, solidaridades en la Europa Medieval, Actas XIX Semana de Estudios Medievales, Estella 92, 1992.

Chirot, Daniel "Gypsies and Other Itinerant Groups: A Socio-Historical Approach", in Journal of Interdisciplinary History - Volume 30, Number 2, 1999, pp. 306-308.

Crofton, H. T., "Early Annals of the Gypsies in England," in Journal of the Gypsy Lore Society, 1, 1888/89.

Davies, C. S. L., "Slavery and protector Somerset; The Vagrancy Act of 1547", in The Economic History Review, New Series, vol. 19, no. 3 (1966), pp. 533-549.

Foletier, F. de Vaux de, Les Tsiganes dans l'ancienne France, 1961.

Geremek, Bronislaw, "Mouvements hérétiques et déracinement social au bas Moyen Age," in Annales. Économies. Sociétés. Civilisations, 37e année $-\mathrm{n}^{\mathrm{o}} 1$, Janvier-Février, Paris, 1982, pp. 186-192.

Hancock, Ian F., The Pariah Syndrome, http://www.geocities.com/Paris/5121/ pariah-ch7.htm.

Hufton, Olwen, "Begging, vagrancy, vagabondage and the law: an aspect of the problem of poverty in Eighteenth century France," European Studies Review, 2, 1972.

Hufton, Olwen, The Poor of Eighteenth-Century France. 1750-1789, Oxford, 1974.

Jütte, Robert, Poverty and Deviance in Early Modern Europe, Cambridge, 1994.

Leblon, Bernard, "Les Gitans dans la Péninsule Ibérique", IN Études Tsiganes. Bulletin de l'Assiciation des Etudes Tsiganes, 10e annee, $\mathrm{n}^{\circ} \mathrm{s} 1$ et 2, Mars-Juin, 1964, pp. 1-24 e no 3, Octobre, 1964, pp. 1-28.

Luis Vives, Jean, "Del socorro de los pobres, o de las necesidades humanas," Biblioteca de autores españoles, volume LXV, Madrid, 1953.

Martz, Linda, Poverty and welfare in Habsburg Spain, Cambridge, 1983.

Mattoso, José, "O ideal da pobreza e as ordens monásticas em Portugal durante os séculos XI-XIII", in A Pobreza e a Assistência aos Pobres na Península Ibérica durante a Idade Média, tome II, Lisboa, 1973, pp. 637-670.

Mollat, Michel, "Les problèmes de la Pauvreté," in Études sur l'Histoire de la Pauvreté, Michel Mollat (ed), Paris, 1974. 
Mollat, Michel, "Pauvres et assistes au Moyen Age," in A Pobreza e a Assistência aos Pobres na Península Ibérica durante a Idade Média. Actas das $1^{\text {as }}$ Jornadas Luso-Espanholas de História Medieval, Lisboa 25-30 de Setembro de 1972, tome I, Lisboa, 1973, pp. 13-15.

Moreno, Humberto Baquero, Exilados, Marginais e Contestatários na Sociedade Portuguesa Medieval, Lisboa, 1990.

Moreno, Humberto Baquero, Marginalidade e Conflitos Sociais em Portugal nos Séculos XIV e XV, Lisboa, 1985.

Sousa, Armindo, As cortes medievais portuguesas (1385-1490), Porto, 1990.

Todd, M., Christian Humanism and the Puritan Social Order, Cambridge, 1987.

Torres Fontes, Juan, "El concepto concejil Murciano de Limosna en el siglo XV", in A Pobreza e a Assistência aos Pobres na Peninsula Ibérica durante a Idade Média, tome II, Lisboa, 1973, pp. 839-859.

Torres, Rui Abreu, "Mendicidade" and "Vadiagem", in Dicionário de História de Portugal (Joel Serrão dir.), volume IV, pp. 254-255; volume VI, pp. 239-240.

Vicente, Gil, Farsa das Ciganas, 1521 or 1525.

Xavier, Ângela Barreto, "Amores e desamores pelos pobres," in Lusitania Sacra, 2a série, 11, 1999, pp. 59-85. 